\title{
Intracranial administration of deglycosylated C-terminal-specific anti-A $\beta$ antibody efficiently clears amyloid plaques without activating microglia in amyloid-depositing transgenic mice Niki C Carty ${ }^{1}$, Donna M Wilcock ${ }^{1}$, Arnon Rosenthal ${ }^{2}$, Jan Grimm², Jaume Pons ${ }^{2}$, Victoria Ronan ${ }^{1}$, Paul E Gottschall ${ }^{1}$, Marcia N Gordon ${ }^{1}$ and Dave Morgan*1
}

Address: ${ }^{1}$ Alzheimer's Research Laboratory, University of South Florida, Department of Molecular Pharmacology and Physiology, 12901 Bruce B Downs Blvd, Tampa, FL 33612, USA and ${ }^{2}$ Rinat Neuroscience Corp. 3155 Porter Drive, Palo Alto, California, 94304, USA

Email: Niki C Carty - ncarty@ hsc.usf.edu; Donna M Wilcock - dwilcock@hsc.usf.edu; Arnon Rosenthal - ar@rinatneuro.com; Jan Grimm - grimm@rinatneuro.com; Jaume Pons - jaume@rinatneuro.com; Victoria Ronan - victoria@mail.usf.edu;

Paul E Gottschall - pgottsch@hsc.usf.edu; Marcia N Gordon - mgordon@hsc.usf.edu; Dave Morgan* - dmorgan@hsc.usf.edu

* Corresponding author

Published: 10 May 2006

Journal of Neuroinflammation 2006, 3:1 I doi:10.1186/1742-2094-3-II
Received: 03 January 2006

Accepted: 10 May 2006

This article is available from: http://www.jneuroinflammation.com/content/3/I/I I

(C) 2006 Carty et al; licensee BioMed Central Ltd.

This is an Open Access article distributed under the terms of the Creative Commons Attribution License (http://creativecommons.org/licenses/by/2.0), which permits unrestricted use, distribution, and reproduction in any medium, provided the original work is properly cited.

\begin{abstract}
Background: Antibodies against the $A B$ peptide clear $A B$ deposits when injected intracranially. Deglycosylated antibodies have reduced effector functions compared to their intact counterparts, potentially avoiding immune activation.
\end{abstract}

Methods: Deglycosylated or intact C-terminal specific high affinity anti-A $\beta$ antibody (2H6) were intracranially injected into the right frontal cortex and hippocampus of amyloid precursor protein (APP) transgenic mice. The untreated left hemisphere was used to normalize for the extent of amyloid deposition present in each mouse. Control transgenic mice were injected with an antibody against a drosophila-specific protein (amnesiac). Tissues were examined for brain amyloid deposition and microglial responses 3 days after the injection.

Results: The deglycosylated $2 \mathrm{H} 6$ antibody had lower affinity for several murine $\mathrm{Fc} \gamma$ receptors and human complement than intact $2 \mathrm{H} 6$ without a change in affinity for $\mathrm{A} B$. Immunohistochemistry for $A \beta$ and thioflavine-S staining revealed that both diffuse and compact deposits were reduced by both antibodies. In animals treated with the intact $2 \mathrm{H} 6$ antibody, a significant increase in Fc $\gamma$-receptor II/ III immunostaining was observed compared to animals treated with the control IgG antibody. No increase in Fc $\gamma$-receptor II/III was found with the deglycosylated $2 \mathrm{H} 6$ antibody. Immunostaining for the microglial activation marker CD45 demonstrated a similar trend.

Conclusion: These findings suggest that the deglycosylated $2 \mathrm{H} 6$ is capable of removing both compact and diffuse plaques without activating microglia. Thus, antibodies with reduced effector functions may clear amyloid without concomitant immune activation when tested as immunotherapy for Alzheimer's disease. 


\section{Introduction}

The molecular mechanisms underlying Alzheimer's disease (AD) have been extensively investigated. AD can occur as a result of genetic mutations in the genes encoding presenilin 1, presenilin 2, or amyloid precursor protein (APP). These genetic alterations accelerate the pathological characteristics of $\mathrm{AD}$, including the formation of extracellular amyloid plaques and the formation of intracellular neurofibrillary tangles consisting of hyperphosphorylated tau. The accumulation of these amyloid plaques are not only a crucial factor in the pathology of $\mathrm{AD}[1]$, but have been argued to contribute to the distinctive clinical symptoms of $\mathrm{AD}$ such as progressive cognitive decline, loss of memory and decreased mental capacity $[2,3]$. Consequently, reducing $\beta$-amyloid $(A \beta)$ in brain has been a primary focus in the treatment of Alzheimer's disease.

Active immunizations using $A \beta_{1-42}$ vaccine was first described by Schenk et al. (1999). This demonstrated that immunotherapy could be a successful means of significantly reducing A $\beta$ deposits in amyloid depositing PDAPP transgenic mice. Not only have vaccinations with $A \beta_{1-42}$ been shown to prevent plaque formation when initiated before the onset of amyloid deposit formation but can also reduce pre-existing brain amyloid [4]. Moreover, Janus et al. and Morgan et al. [5,6] demonstrated that vaccines against $A ß$ could also protect APP transgenic mice from developing memory impairments. These observations initiated clinical trails in which patients with mild to moderate $\mathrm{AD}$ were given an active immunization (AN1792); [7-9]. These Phase IIa trials were interrupted due to the occurrence of meningoencephalitis in $6 \%$ of the patients [10].

Consequently, passive immunization became considered as a possibly safer and more controllable means of removing $A \beta$ deposits from the brain. Immunization with antiA $\beta$ monoclonal antibodies has been demonstrated to be an efficient and effective means of clearing $A \beta$ plaques with both prolonged systemic administration and intracranial injections of antibody [11-14]. In addition, passive immunization rapidly reversed cognitive deficits and memory loss in amyloid depositing transgenic mouse models $[15,16]$.

Despite the initial promise of passive immunization as effective and practical treatment for $A D$, recent studies have demonstrated potentially harmful aspects of $\mathrm{A} \beta$ passive immunotherapy in mouse models of amyloid deposition. In several experiments administration of at least two different monoclonal anti-A $\beta$ IgG's resulted in significant increases in occurrence and severity of cerebral hemorrhage when compared to controls [17-19]. Wilcock et al. [18] also showed an increase of cerebral amyloid angi- opathy (CAA) in association with increases in vascular leakage. Microglial activation has been shown surrounding amyloid-containing blood vessels following systemic passive immunization and could potentially be one of the mechanisms that increase the likelihood of microhemorrhage [18].

In the present study we investigate the efficacy of a modified (deglycosylated) antibody with decreased affinity for the Fc $\gamma$ receptor (Fc $\gamma-\mathrm{R} ;[20])$ for its ability to eliminate $A \beta$ from the brain without increasing microglial activation. This will inform us if future passive immunization studies may use this modification to clear $A \beta$ without activating microglia, and test the role of the microglial activation through Fcy-R activation on vascular amyloid deposition and increased susceptibility to microhemorrhage.

\section{Materials and methods \\ Antibody preparation}

Antibody 2H6 is raised against aa33-40 of human Aß. The antibody binds Aß terminating at position 40 preferentially over peptides ending at position 42 and is of the murine IgG2b isotype. To generate deglycosylated $2 \mathrm{H} 6$ (de-2H6), N-linked carbohydrate groups on the Fc portion of the antibody were enzymatically removed by treatment with peptide-N-glycosidase F (QA-Bio, San Mateo). The antibody was incubated for 7 -days at $37^{\circ} \mathrm{C}$; with 0.05 $\mathrm{U}$ of enzyme per $\mathrm{mg}$ of antibody in $20 \mathrm{mM}$ Tris- $\mathrm{HCl} \mathrm{pH}$ $8.0 ; 0.01 \%$ Tween. The deglycosylated antibody was protein A purified and endotoxin was removed by Q-Sepharose anion exchange chromatography. Complete removal of N-linked glycans was verified by MALDI-TOF-MS and protein gel electrophoresis.

Binding affinity of $2 \mathrm{H} 6$ and de-2H6 antibodies to FCy receptors or complement protein $\mathrm{C} 1 \mathrm{q}$ were also measured using BIAcore. Purified murine Fc $\gamma$ receptors (from R\&D Systems) and human C1q (from Quidel) were immobilized on BIAcore CM5 chip by amine chemistry: Fc $\gamma$ receptors or $\mathrm{C} 1 \mathrm{q}$ were diluted into $10 \mathrm{mM}$ sodium acetate $\mathrm{pH}$ 4.0 and injected over an EDC/NHS activated chip at a concentration of $0.005 \mathrm{mg} / \mathrm{mL}$. Variable flow time across the individual chip channels were used to obtain 2000-3000 response units (RU). The chip was blocked with ethanolamine. Serial dilutions of monoclonal antibodies (ranging from $2 \mathrm{nM}$ to $70 \mu \mathrm{m}$ ) were injected. HBS-EP (0.01 M HEPES, pH 7.4, $0.15 \mathrm{M} \mathrm{NaCl}, 3 \mathrm{mM}$ EDTA, $0.005 \%$ Surfactant P20) was used as running and sample buffer. Regeneration studies showed that a mixture of Pierce elution buffer (Product No. 21004, Pierce Biotechnology, Rockford, IL) and $4 \mathrm{M} \mathrm{NaCl} \mathrm{(2:1)} \mathrm{effectively}$ removed the bound antibody peptide while keeping the activity of $\mathrm{F} C \gamma$ receptors and $\mathrm{C} 1 \mathrm{q}$. Binding affinities of $A ß$ for the antibodies was determined similarly by immobilizing the antibodies on a CM5 chip using amine chemis- 
try, and flowing AB1-40 over the chip at multiple concentrations. Binding data were analyzed using 1:1 Langmuir interaction model for high affinity interactions, or steady state affinity model for low affinity interactions.

\section{Experimental design}

Transgenic mice. Tg2576 APP mice [2]) were acquired from the breeding colonies at the University of South Florida. Multiple mice were housed together whenever possible until the time of use for the study; mice were then singly housed just before surgical procedures until the time of sacrifice. Study animals were given water and food (ad libitum) and maintained on the twelve hour light/dark cycle and standard vivarium conditions. Two cohorts of mice were used, the first cohort consisted of mice aged 20 months $(n=13)$ and the second cohort consisted of mice aged 13 months $(n=15)$. Animals in each cohort were assigned to one of three groups. Group one received a Cterminal high affinity anti-A $\beta$ antibody $2 \mathrm{H} 6$ (Rinat Neurosciences, Palo Alto, CA; $n=12$; five 20 mo and seven 13 mo). Group two received de-2H6 antibody (Rinat Neuroscience; $n=8$; four $20 \mathrm{mo}$ and four $13 \mathrm{mo}$ ). Group three received a control antibody (also isotype IgG2b), directed against a drosophila protein, amnesiac, without a mammalian homologue (2908, Rinat Neuroscience) $(n=8$; four $20 \mathrm{mo}$ and four $13 \mathrm{mo}$ ). Overall measures of Aß load and Thioflavin $S$ load were greater in the older mice.. Although there was a trend for greater fractional reductions of $A ß$ by $2 \mathrm{H} 6$ and de-2H6 in younger mice, these observations were not consistent. Fractional reduction of Thioflavine $S$ staining by antibodies was unaffected by the age of the mouse.

\section{Surgical procedure}

Immediately before surgery mice were weighed then anesthetized using isoflurane. Surgery was performed on animals using a stereotaxic apparatus. The cranium was exposed using an incision through the skin along the median sagittal plane, and two holes were drilled through the cranium over the right frontal cortex injection site and the right hippocampal injection site. Previously determined coordinates for burr holes, taken from bregma were as follows; frontal cortex, anteroposterior, $-1.5 \mathrm{~mm}$; lateral, $-2.0 \mathrm{~mm}$, vertical, $3.0 \mathrm{~mm}$, hippocampus, anteroposterior, $-2.7 \mathrm{~mm}$; lateral $-2.5 \mathrm{~mm}$, vertical, $3.0 \mathrm{~mm}$. Burr holes were drilled using a dental drill bit (SSW HP-3, SSWhite Burs Inc., Lakewood, NJ). Injections of $2 \mu \mathrm{g}$ antibody in $2 \mu \mathrm{l}$ saline were dispensed into hippocampus and frontal cortex over a period of $4 \mathrm{~min}$. using a 26 gauge needle attached to a $10 \mu \mathrm{l}$ syringe (Hamilton Co., Reno, $\mathrm{NV}$ ). The incision was then cleaned and closed with surgical staples. Animals were recovered within 10 minutes and housed singly until time of sacrifice.

\section{Immunohistochemistry}

Three days post surgery, mice were weighed, overdosed with pentobarbital ( $200 \mathrm{mg} / \mathrm{kg}$; ) and perfused with $25 \mathrm{ml}$ of $0.9 \%$ normal saline solution then $50 \mathrm{ml}$ of freshly prepared 4\% paraformaldehyde. Brains were collected from the animals immediately following perfusion and immersion fixed in $4 \%$ paraformaldehyde for 24 hrs. Mouse brains were cryoprotected in successive incubations in $10 \%, 20 \%, 30 \%$ solutions of sucrose; 24 hrs in each solution. Subsequently, brains were frozen on a cold stage and sectioned in the horizontal plane ( $25 \mu \mathrm{m}$ thickness) on a sliding microtome and stored in Dulbecco's phosphate buffered saline (DPBS) with $0.2 \%$ sodium azide solution at $4{ }^{\circ} \mathrm{C}$.

Six sections $100 \mu \mathrm{m}$ apart spanning the site of injection were chosen and free-floating immunochemical and histological analysis was performed to determine total $A \beta$ using a rabbit anti-Aß serum at a concentration 1:10,000 (Serotec, Raleigh, NC), CD45 expression using rat antimouse monoclonal IgG; 1:5000 (Serotec, Raleigh, NC), and Fc $\gamma$-receptor-II/III (Fc $\gamma$-R) expression using rat antimouse monoclonal IgG; 1:1000 (BD Biosciences, San Diego, CA). A fourth series of sections were mounted on slides and stained with thioflavine-S (1\%; Sigma Aldrich, St. Louis, MO) to assess compact plaque deposition. Immunohistochemical procedural methods were analogous to those described by Gordon et al. 2002 for each marker. Six sections from each animal were placed in multisample staining tray and endogenous peroxidase blocked (10\% methanol, $30 \% \mathrm{H}_{2} \mathrm{O}_{2}$ in PBS). Tissue samples were then permeabilized (with lysine $0.2 \%, 1 \%$ Triton X-100 in PBS solution), and incubated overnight in appropriate primary antibody. Sections were washed in PBS then incubated in corresponding biotinylated secondary antibody (Vector Laboratories, Burlingame, CA). The tissue was again washed after a 2 hr. incubation period and incubated with Vectastin ${ }^{\circledast}$ Elite $^{\circledast}$ ABC kit (Vector Laboratories, Burlingame, CA) for enzyme conjugation. Finally, sections were stained using $0.05 \%$ diaminobenzidine and $0.3 \% \mathrm{H}_{2} \mathrm{O}_{2}$ (for CD45 and $\mathrm{Fc} \gamma \mathrm{R}$ $0.5 \%$ nickelous ammonium sulfate was added for color enhancement). Tissue sections were mounted onto slides, dehydrated, and coverslipped. Each immunochemical assay omitted some sections from primary antibody incubation period to evaluate nonspecific reaction of the secondary antibody.

Stained sections were imaged using an Evolution MP digital camera mounted on an Olympus BX51 microscope at $100 \times$ final magnification $(10 \times$ objective). Six horizontal brain sections (100 $\mu \mathrm{m}$ apart; every $4^{\text {th }}$ section) were taken from each animal and four nonoverlapping images near the site of injection from each of these sections were captured (24 measurements per mouse). All images were 

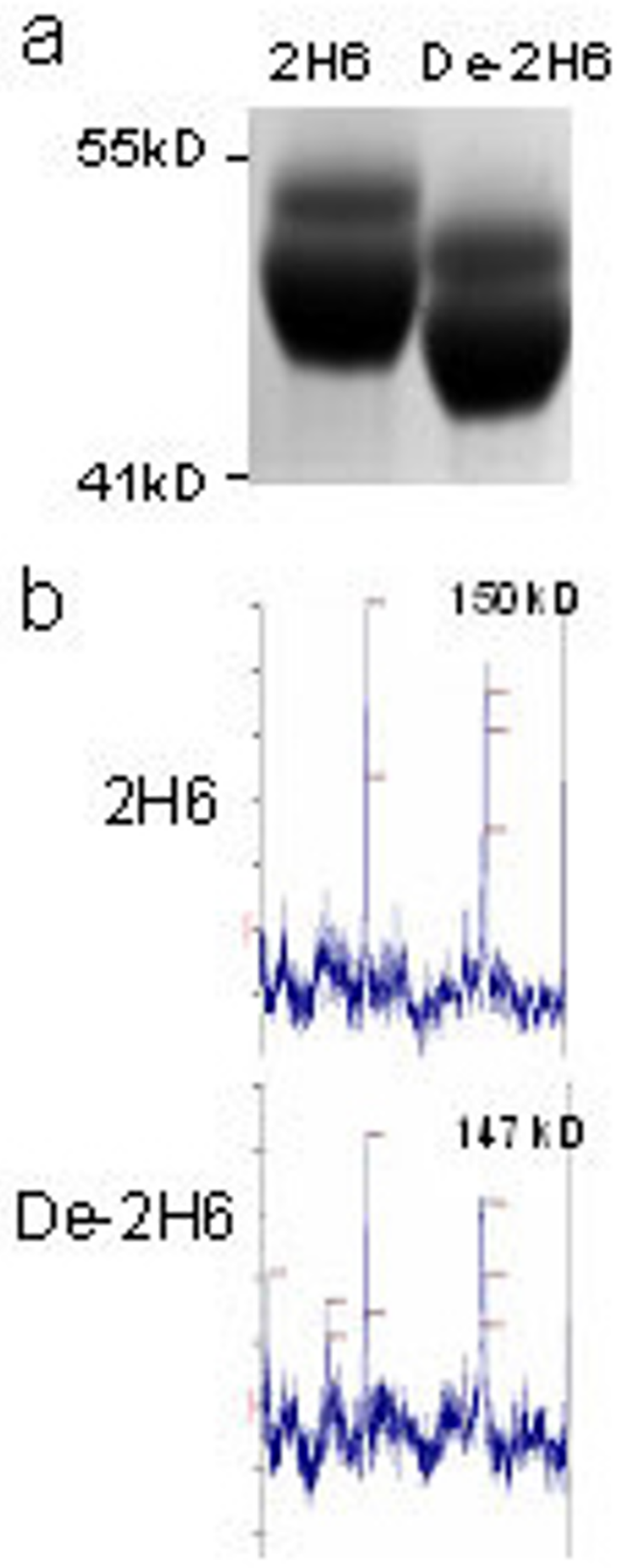

\section{Figure I}

Verification of deglycosylation of de-2H6 by and MALDI-TOF-MS and SDS-PAGE. Panel A. SDS-PAGE analysis of 2 H6 and de2H6. Samples were size fractionated under denaturing conditions on a 3-8\% Tris-Acetate Gel and stained with Coomassie blue. Note the lower apparent molecular weight for the deglycosylated heavy chain doublet. Panel B. MALDI-TOF-MS analysis revealed the expected $2 \%$ reduction in molecular weight after removal of $\mathrm{N}$-linked glycans in the de- $2 \mathrm{H} 6$ antibody 
Table I: Affinities (Kd) of $\mathbf{2 H} 6$ and De-2H6 for antigen and effector proteins

\begin{tabular}{lccccc}
\hline Antibody & $\mathrm{ABI}-40(\mathrm{nM})$ & $\mathrm{mFc} \gamma \mathrm{RI}(\mu \mathrm{M})$ & $\mathrm{mFc} \gamma \mathrm{RIlb}(\mu \mathrm{M})$ & $\mathrm{mFc} \gamma \mathrm{RIII}(\mu \mathrm{M})$ & $\mathrm{hClq}(\mu \mathrm{M})$ \\
\hline $2 \mathrm{H} 6$ & 8 & 1.6 & 20 & 39 & 5 \\
De-2H6 & 9 & 6.5 & 30 & 67 & 30 \\
\hline
\end{tabular}

taken from the same location in all animals. Quantification of positive staining product surrounding and including the injection sites in the right frontal cortex and the right hippocampus and the corresponding regions in the left hemisphere were determined using Image-Pro ${ }^{\circledast}$ Plus (Media Cybernetics ${ }^{\circledast}$, Silver Springs, MD). Ratios of the right and left regions were calculated (to normalize for variability in amyloid deposition between animals) and ANOVA statistical analysis was performed using StatView ${ }^{\circledast}$ version 5.0.1 (SAS Institute, Raleigh, NC).

\section{Results}

\section{Antibody deglycosylation}

The treatment with peptide- $\mathrm{N}$-glycosidase $\mathrm{F}$ appeared to completely remove the single carbohydrate chain associated with the Fc component of IgG for antibody 2H6. This was apparent both by mobility shift on polyacrylamide gel analysis of the denatured IgG heavy chain (Fig 1a) and by a shift in molecular weight by MALDI-TOF analysis of the native IgG complex (Fig 1b).

Deglycosylation had no effect on the affinity of $2 \mathrm{H} 6$ for its antigen, Aß1-40, but exhibited reduced binding to its effector proteins responsible at least in part for the activation of microglia and other cells in association with antigen opsonization (table 1).

\section{Amyloid clearance}

Intracranial injections of the intact $2 \mathrm{H} 6$ antibody, de-2H6 antibody and control IgG were administered to APP mice and immunohistochemistry was performed on fixed brain tissue to determine amount of plaque clearance. Total $\mathrm{A} \beta$ load was ascertained 3 days after intracranial injections by immunohistochemical methods using a polyclonal anti $A \beta$ antiserum which primarily recognizes the $N$-terminal domain of $A \beta$, and thus labels both $A \beta_{1-40}$ and $A \beta_{1-42}$ (the time course of $A \beta$ clearance and diffusion patterns of injected anti-A $\beta$ antibodies were presented by Wilcock et al., (2003)[14]). The regional A $\beta$ distribution and density in APP transgenic mice were similar to those reported by Gordon et al. and Hsiao et al. [21,2]. Immunohistochemistry revealed darkly stained compact plaques and more lightly stained diffuse plaque deposits containing fibrillar and nonfibrillar $\beta$-amyloid in the APP animal tissue (Fig 2A). Plaque deposition was distributed throughout the cortical regions as well as in the hippocampus (although most concentrated in the molecular layers of the dentate gyrus and the CA1 region, surrounding the hippocampal fissure). A notable decrease in the amount of hippocampal $A \beta$ staining was observed in animals injected with intact $2 \mathrm{H} 6$ and de-2H6 antibodies (Fig. 2C and 2E) $72 \mathrm{hrs}$ after time of injection in comparison to control animals receiving the anti-amnesiac IgG (Fig 2A). Animals injected with the control antibody showed $A \beta$ immunohistochemical staining patterns throughout the cortex and hippocampus comparable to those of untreated APP transgenic mice of the same age. The reductions in $A \beta$ deposition were limited to the areas surrounding the cortical and hippocampal injection sites. ANOVA analysis of animals injected with the intact $2 \mathrm{H} 6 \mathrm{IgG}$ showed significant reduction $(72 \%)$ in the hippocampus and a significant reduction $(76 \%)$ in the frontal cortex compared to animals treated with the control IgG (Fig. 2G). Mice treated with the de-2H6 showed significant reductions in both the hippocampus $(69 \%)$ and in the frontal cortex $(76 \%)$. In neither region was there a difference between mice treated with $2 \mathrm{H} 6$ compared to mice treated with de-2H6.

As noted by our previous work [14] thioflavine-S staining labels compact fibrillar amyloid plaques, but not the more diffuse $A \beta$ staining. The thioflavine-S positive plaque deposition was homogeneously distributed throughout the frontal cortical regions, but in hippocampus was concentrated along the hippocampal fissure and into the dentate gyrus (Fig 3A). The density of thioflavine$S$ staining was substantially less than $A \beta$ immunochemistry staining. Antibody administration reduced thioflavine$S$ positive staining three days after antibody administration (Fig. 3C and 3E). Quantification of positive staining at the site of injection in animals receiving the de-2H6 anti-A $\beta$ antibody showed a significant reduction (55\%) in the hippocampus and a significant reduction $(70 \%)$ in the frontal cortex compared to mice injected with the control antibody (Fig 3G). Injection of intact 2H6 caused significant reduction $(75 \%)$ in positive staining in the frontal cortex, but the $35 \%$ reduction in hippocampal plaque load did not reach significance compared to the control antibody values (Fig. 2G). Again, no differences were found when the intact and the deglycosylated anti-Aß antibody groups were compared. Vascular $A \beta$ levels were calculated by measuring thioflavine $S$ stained area after digitally editing out parenchymal (plaque) deposits. No significant changes in vascular $A \beta$ were seen with the intact or deglycosylated anti-A $\beta$ antibody groups when compared to control animals. 

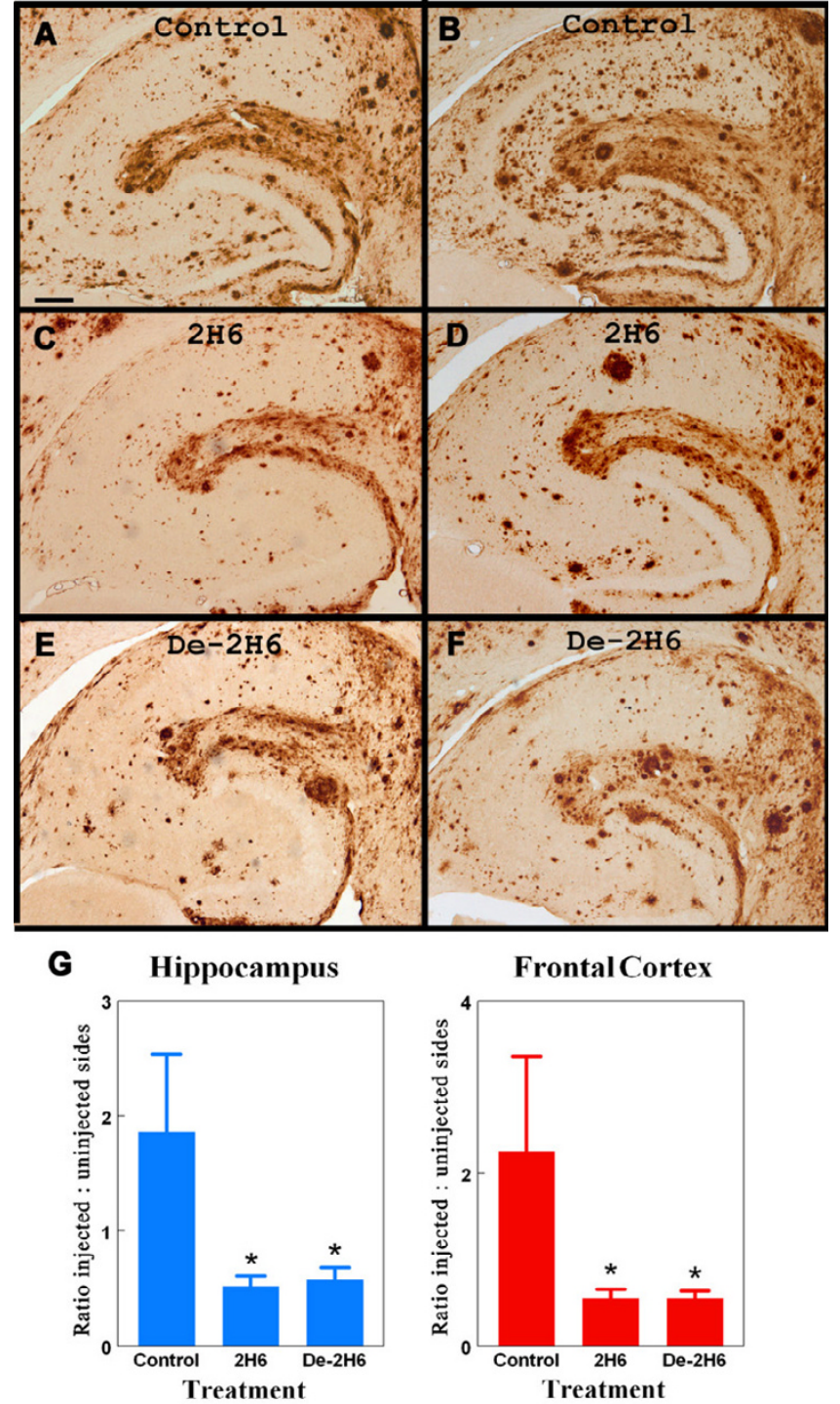

Figure 2

Total $A B$ load is reduced following intracranial administration of intact anti-A $\beta$ antibody and deglycosylated anti-A $\beta$ antibody. Panels $B, D$, and $F$ show total $A \beta$ immunostaining in the left (untreated) hippocampal regions of $20 \mathrm{mo}$. old APP transgenic mice. Panels $A, C$, and $E$ show total $A \beta$ staining in right hippocampal regions of 20 mo. old APP transgenic mice receiving intracranial injection of control antibody (panel $A$ ) or anti-A $\beta$ C-terminal antibody (2H6; panel $\mathrm{C})$, or deglycosylated anti-A $\beta$ C-terminal antibody (de-2H6; panel E). Magnification $=40 \times$, scale bar $=50 \mathrm{~mm}$. Panel G shows quantification of the $A B$ load as the ratio of injected (right) side to uninjected (left) side for both the hippocampal and frontal cortical injection sites * indicates $\mathrm{P}<0.05$ compared to mice injected with control lgG.
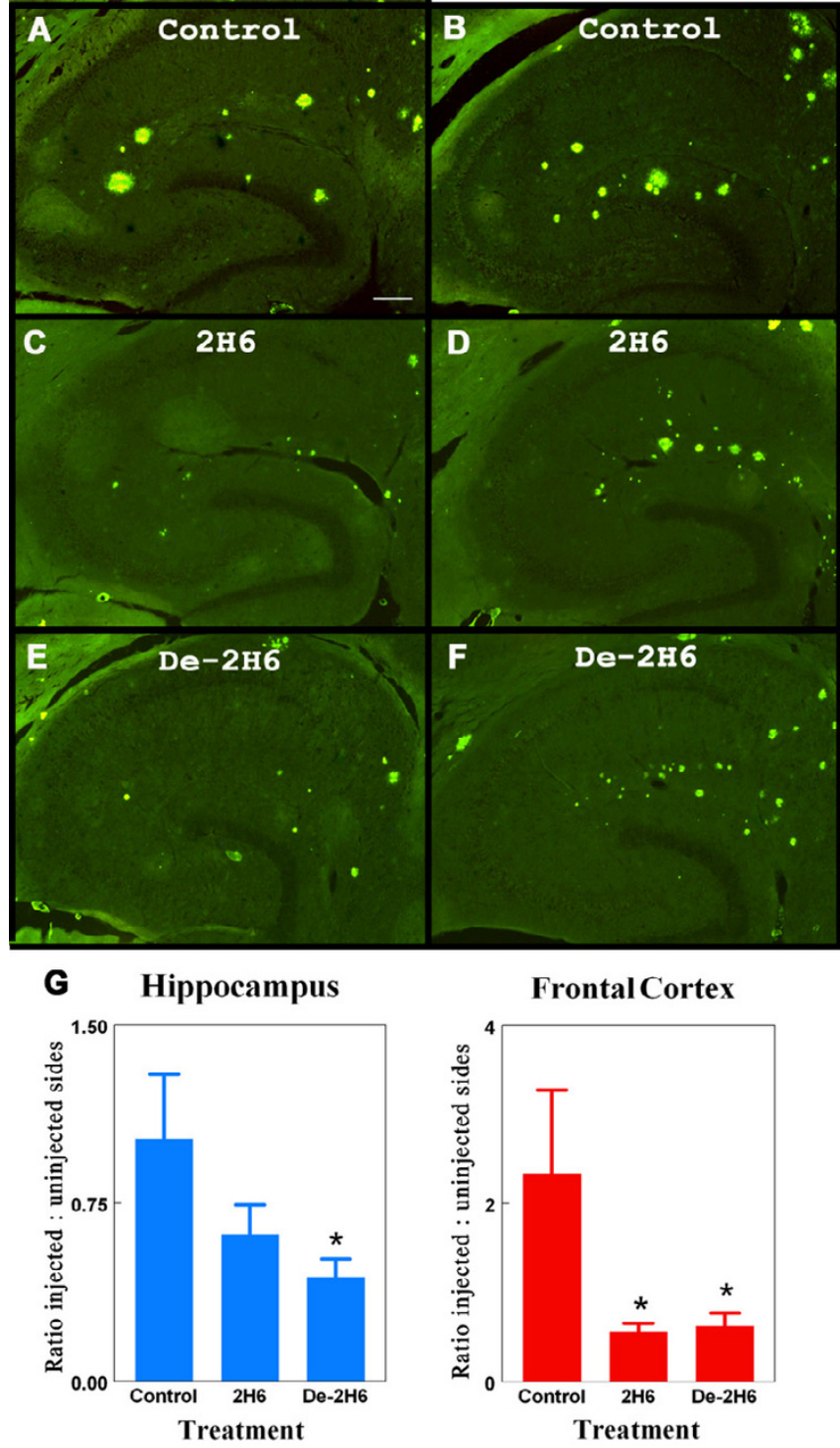

Figure 3

Thioflavine $\mathrm{S}$ labeled compact amyloid deposits are reduced following intracranial administration of anti-A $\beta$ antibody. Panels $B, D$, and $F$ show total thioflavine $S$ staining of compact amyloid deposits in left (untreated) hippocampal regions of 20 mo. old APP transgenic mice. Panels A, C, and E show total thioflavine $S$ staining in right hippocampal regions of 20 mo. old APP transgenic mice receiving intracranial injection of control antibody (panel $A$ ) or anti-A $\beta$ C-terminal antibody (2H6; panel $\mathrm{C}$ ), or deglycosylated anti-A $\beta \mathrm{C}$-terminal antibody (de-2H6; panel E). Magnification $=40 \times$, scale bar $=50$ $\mu \mathrm{m}$. Panel $\mathrm{G}$ shows quantification of the amyloid load as the ratio of injected (right) side to uninjected (left) side for both the hippocampal and frontal cortical injection sites * indicates $\mathrm{P}<0.05$ compared to mice injected with control lgG. 


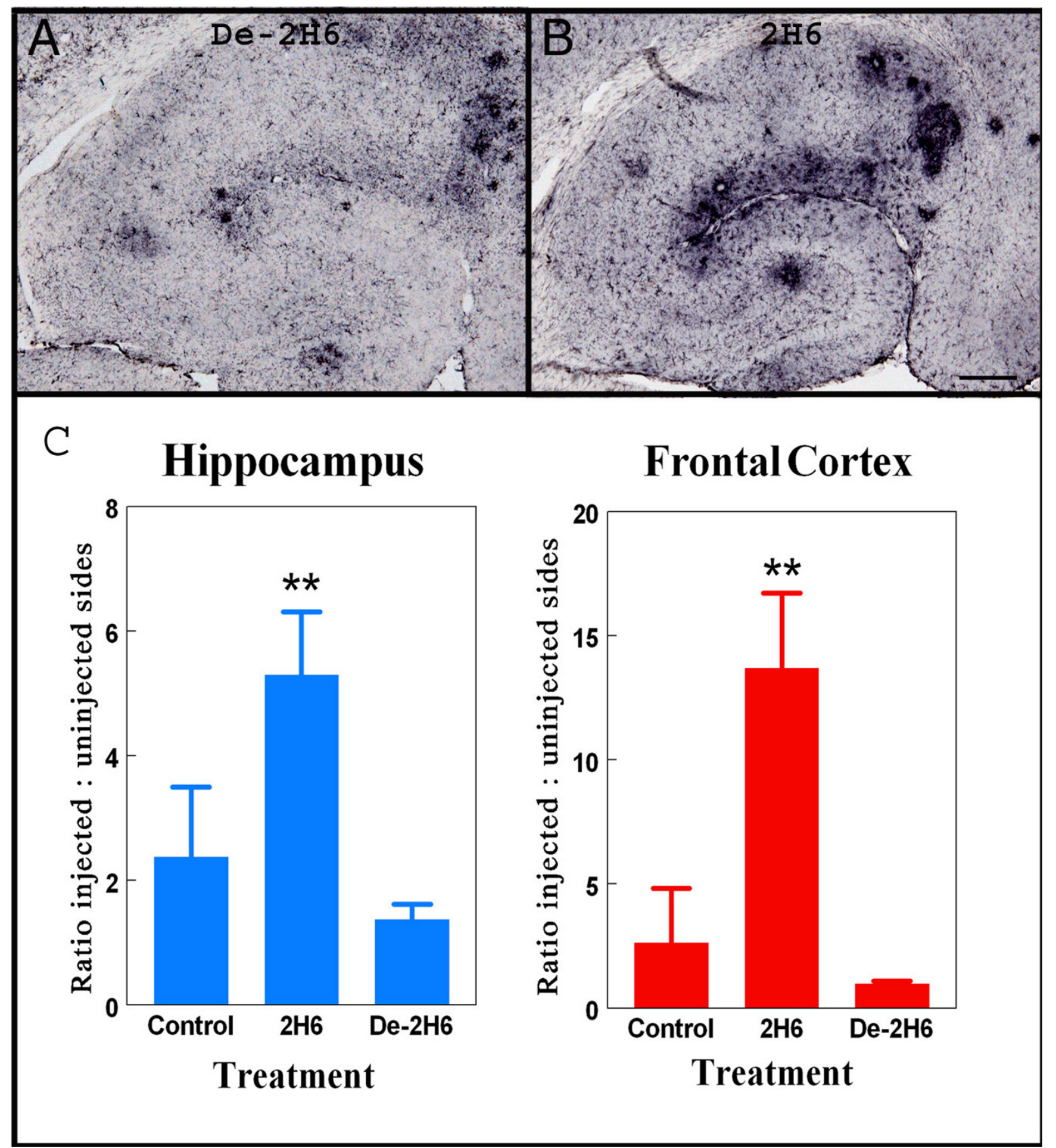

\section{Figure 4}

Fc $\gamma$ receptor expression is increased following intracranial administration of intact anti-A $\beta$ antibody but not deglycosylated anti-A $\beta$ antibody. Panels $A$ and B show Fc $\gamma$-receptor II/III staining in right hippocampal regions of 20 mo. old APP transgenic mice receiving intracranial injection of deglycosylated $C$-terminal anti-A $\beta$ antibody (de-2H6) (panel $A$ ) or intact anti-A $\beta$ C-terminal antibody $(2 \mathrm{H} 6$; panel $\mathrm{B})$. Magnification $=40 \times$, scale bar $=50 \mu \mathrm{m}$. Panel $\mathrm{C}$ shows quantification of the Fc $\gamma-\mathrm{R}$ immunostaining as the ratio of injected (right) side to uninjected (left) side for both the hippocampal and frontal cortical injection sites. $* *$ Indicates $\mathrm{P}<0.0$ I versus both control IgG and de- $2 \mathrm{H} 6$. 


\section{Microglial activation}

After determining efficacy of $2 \mathrm{H} 6$ and de-2H6 were similar in clearance of both diffuse and compact $A \beta$, we examined microglial activation by looking at Fc $\gamma$-R expression and CD45 expression. In prior work we found that antibody opsonized antigens in brain increase microglial expression of $\mathrm{Fc} \gamma-\mathrm{R}$, presumably to aid in phagocytosis of the opsonized material [22]. The staining patterns in animals injected with de-2H6 and control antibody were similar to that of untreated APP transgenic mice (Fig. 4A). All animals demonstrated the most intense activation in areas immediately surrounding $\mathrm{A} \beta$ plaques within the dentate gyrus and near the fissure. Fc $\gamma$-R immunohistochemistry for mice receiving the intact $2 \mathrm{H} 6$ antibody was increased considerably both near the amyloid deposits, and to a lesser extent throughout the hippocampus (Fig 4B). Quantification and ANOVA analysis of Fc $\gamma$-R expression levels revealed a significant fivefold increase in the frontal cortex and hippocampus in animals receiving the 2H6 antibody compared to mice receiving either the control anti-amnesiac IgG or the de-2H6. In contrast, the group receiving intracranial administration of de-2H6 showed no changes in Fc $\gamma$-R expression when compared to the control antibody group (Fig. 4C).

The staining patterns of the CD45 antibody were similar to patterns seen in tissue stained for Fcy-R expression (Fig $5 \mathrm{~A})$. However, there was a slightly greater degree of microglial activity in the right hemisphere at the location of needle entry relative to the uninjected side due to mechanical injury from the injection procedure. In mice treated with the $2 \mathrm{H} 6$ antibody there was a significant elevation in activated microglia as detected by CD45 immunohistochemistry (Fig 5B.). Activated microglial patterns in animals treated with intact $2 \mathrm{H} 6$ were fairly widespread but slightly more concentrated staining was observed in areas immediately surrounding $A \beta$ plaques as well as areas surrounding the sites of injection in the frontal cortex and hippocampus (Fig. 5B). Quantitative analysis showed a dramatic increase, approximately sixfold, in microglial expression in the animals receiving $2 \mathrm{H} 6$ compared to those animals receiving control antibody or the de-2H6 in frontal cortex (Fig 5C). A less dramatic, but similar trend was observed in the hippocampus. Brains injected with the de-2H6 showed no significant changes compared to control mice, and were significantly lower than the mice injected with intact $2 \mathrm{H} 6$ in the frontal cortex 3 days after treatment (Fig 5A; 5C).

\section{Discussion}

The formation and deposition of amyloid plaques composed largely of aggregated $A \beta$ peptides is an invariant feature of $\mathrm{AD}$, and several studies find inverse correlations with cognitive function [23-25]. There is a strong correlation between $A \beta$ loads and cognitive function in APP transgenic mice $[26,27,19,28,29]$. A number of studies have demonstrated that passive immunization with anti$\mathrm{A} \beta$ antibodies can remove considerable amounts of $\mathrm{A} \beta$ plaques in the amyloid depositing APP transgenic mice $[11,12,30,13,14,31]$. Immunotherapy with anti-Aß antibodies can also improve memory performance in amyloid depositing APP mice $[6,5,15,16,18]$. The data from this study demonstrate that intracranial administration of either an anti-A $\beta$ antibody which exhibits high affinity for the $\mathrm{C}$ terminal of the $\mathrm{A} \beta$ peptide or its deglycosylated counterpart (with an impaired ability to bind to the Fc effector proteins) provide effective methods by which to remove $A \beta$. Both anti-A $\beta$ antibodies illustrated a considerable capacity to reduce both compact and diffuse $A \beta$ plaque pathology. There were no significant differences between the capacities of these antibodies to remove $A ß$ deposits in spite of the reduced effector activating functions of the deglycosylated variant. It is possible that near the site of injection, most of the removable $A ß$ deposits are cleared by both antibodies. This could suggest that some limit in the extent of clearance is reached rather than suggesting activated microglia have no role in antibodymediated Aß clearance.

The effectiveness of passive $A \beta$ immunotherapy in reversing $\mathrm{AD}$ brain pathology raises questions concerning the underlying mechanisms by which anti-A $\beta$ antibodies produce such dramatic reductions in $\mathrm{A} \beta$ in the brain. Some results argue that amyloid opsonization and Fc $\gamma$-R mediated phagocytosis by microglia is the major mechanism by which $A \beta$ is removed from the brain $[4,11,14,32]$. Other experiments, using the same intracranial approach described here, suggested that the activation of microglia can facilitate the removal of $\mathrm{A} \beta$ plaques in the brain, but may not be essential [22].

The observations presented in this study are more consistent with experiments indicating that microglia independent mechanisms can result in the efficient clearance of $A \beta$ plaques. One such mechanism may involve the disruption of plaque by the antibody itself followed by disaggregation or disruption of the $\beta$-sheet conformation of $\mathrm{A} \beta$ and subsequent removal [33]. Data presented by Bacskai et al. showed that $F\left(a b^{\prime}\right)_{2}$ fragments (modified anti-A $\beta$ antibody which lack the complete Fc region) were able to significantly decrease amyloid deposits following administration [12]. Additionally, Das et al. found that vaccination against $A ß$ was able to significantly reduce amyloid deposition in Fc $\gamma$-R knock out mice lacking expression of Fc $\gamma$-RIII and possessing reduced phagocytic function [31]. Another mechanism referred to as the "peripheral sink" first described by DeMattos et al. [30] suggests that decreases in $\beta$-amyloid deposition following immunization is a result of the net efflux of $A \beta$ from the brain to the plasma, facilitated by the antibody acting as a sink in the circulation, which then prevents further deposition of amyloid in the brain. A similar conclusion was drawn 


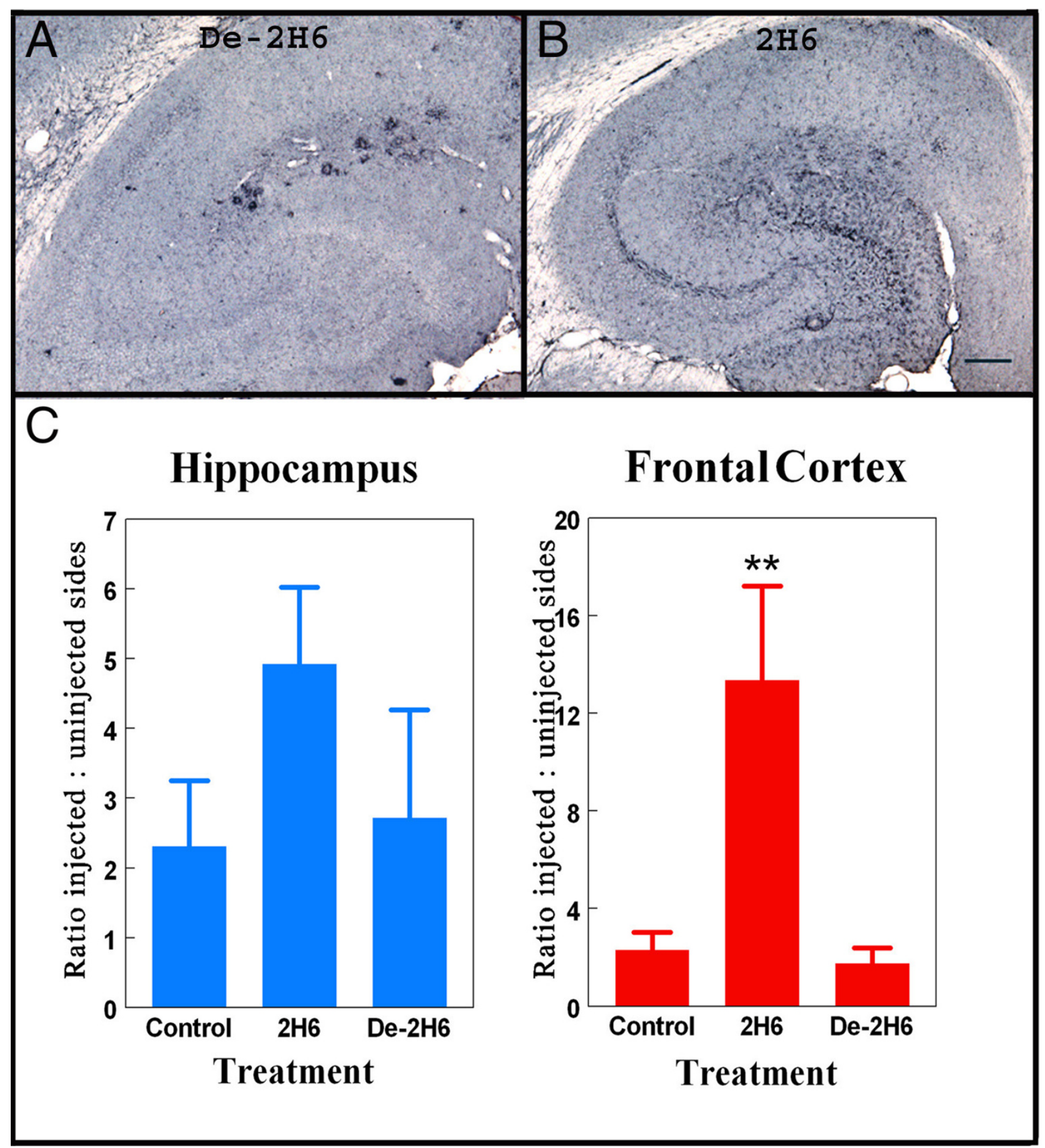

\section{Figure 5}

CD45 expression is increased in mice receiving intracranial administration of intact but not deglycosylated anti-A $\beta$ antibody. Panels $A$ and $B$ show total CD45 staining in right hippocampal regions of 20 mo. old APP transgenic mice receiving intracranial injection of deglycosylated $\mathrm{C}$-terminal anti-A $\beta$ antibody (de-2H6) (panel $\mathrm{A}$ ) or intact anti-A $\beta$ C-terminal antibody (2H6; panel B). Magnification $=40 \times$, scale bar $=50 \mu \mathrm{m}$. Panel $C$ shows quantification of theCD45 immunostaining as the ratio of injected (right) side to uninjected (left) side for both the hippocampal and frontal cortical injection sites $*$ indicates $\mathrm{P}<0.05$ compared to mice injected with control lgG and de-2H6. 
from work with another $A ß$ binding agent, GM1 ganglioside, that increased plasma $A ß$ and reduced central $A \beta$ deposition [34]. It is unlikely this latter alternative is at work in the studies with intracranial administration, but the catalytic disaggregation mechanism is certainly feasible with the intracranial approach. It is further conceivable that centrally applied antibodies may form a sink in the ventricular space of the brain, reducing parenchymal deposits [35]. Most recently, FcRn has been demonstrated to play a substantial role in amyloid removal by anti-Aß immunotherapy, by transporting both antibody into the brain, and antibody-Aß complexes out of the brain[18]. Thus, there are several mechanisms by which anti-Aß immunotherapy may function without requiring activation of effector proteins and activation of microglia or other immune cells. Recent studies indicate that deglycosylation does not affect the capacity for the antibody to bind to the neonatal Fc transport receptor (FcRn; [36]).

The efficacy and success of anti- $\mathrm{A} \beta$ immunotherapy in the treatment of amyloid pathology (reducing $A \beta$ plaque load and reversing or halting cognitive decline) in both mice and humans $[7,8,37,38]$, despite some drawbacks [10], has initiated further exploration into the cellular responses underlying removal of $A ß$ in the brain. Recent experiments with prolonged systemic passive immunization have revealed adverse affects including increases in microhemorrhage in transgenic mice accompanied by reductions in diffuse and fibrillar amyloid $[39,17,19]$. A link between increases in vascular amyloid levels and increases in cerebral hemorrhage following passive immunization was also reported recently [39]. The precise mechanism by which passive immunotherapy leads to increased levels of hemorrhage has not been clearly delineated but it has been proposed that antibody opsonization of vascular amyloid may activate local microglia to produce an inflammatory response $[17,19]$. Additionally, the increases in vascular amyloid levels following passive immunization may result from microglial mediated redistribution of compacted amyloid from the parenchyma to the vessels, further weakening the blood vessels leading to increased susceptibility to cerebral hemorrhage [39]. Regardless of the cause of increased risk of hemorrhage, minimizing the interaction between passively transferred anti-Aß antibodies and effector proteins on the microglial surface may have benefits with respect to microhemorrhage development.

The deglyosylated anti-A $\beta$ antibody used in this study is a modified version of the high affinity C-terminal Aß40specific $2 \mathrm{H} 6$ antibody in which the carbohydrate groups within the Fc portion of the antibody have been removed, significantly impairing its ability to bind to the Fc $\gamma$-receptors of macrophages and, presumably, reducing Fc mediated phagocytosis. A similar effect of deglycosylation on an $\mathrm{N}$ terminal specific anti-Aß antibody was recently reported in vitro [40]. Even though recent trials have exposed some adverse consequences of one $A \beta$ vaccine, the benefits of immunotherapy as a potential treatment for Alzheimer's disease should not be undervalued. The present results suggest that the modified deglycosylated antibody provides an efficient means of removing $A \beta$ from the brain without activating microglia. Emphasis on further exploration into the mechanisms involved in antibody mediated $A \beta$ removal from the brain and elucidation of more effective methods of immunotherapy continues to be an important area of focus in AD therapy.

\section{Competing interests}

A. Rosenthal, J. Grimm and J. Pons are employees and shareholders of Rinat Neurosciences Corporation which holds the patents for the antibodies used in the studies presented here. D. Wilcock has also performed consulting services for Rinat Neurosciences.

\section{Authors' contributions}

Niki Carty performed the surgical procedures, histological measurements and data analysis. She also drafted the first version of the manuscript. Donna Wilcock supervised the surgical procedures and assisted in the histology. Arnon Rosenthal, Jaume Pons and Jan Grimm developed the $2 \mathrm{H} 6$ monoclonal antibody and produced the material for injection. Jaume Pons performed the deglycosylation procedure and measured affinities using the Biacore. Victoria Ronan was responsible for all genotyping of transgenic mice and assisted in maintenance the mouse colony. Paul Gottschall prepared the polyclonal antiserum used for histological measurement of $A ß$ and assisted in manuscript preparation. Marcia Gordon was responsible for tissue collection and data analysis. Dave Morgan was responsible for overseeing all aspects of the study and played the major role in manuscript revision.

\section{Acknowledgements}

We thank Karen Ashe for early access to the Tg2576 transgenic mouse. These data were supported by NIH ROIs AGI5490 and AG 18478. Donna Wilcock is the Benjamin Scholar in Alzheimer's Research

\section{References}

I. Bard F, Barbour R, Cannon C, Carretto R, Fox M, Games D, Guido T, Hoenow K, Hu K, Johnson-Wood K, Khan K, Kholodenko D, Lee C, Lee M, Motter R, Nguyen M, Reed A, Schenk D, Tang P, Vasquez $\mathrm{N}$, Seubert $\mathrm{P}$, Yednock T: Epitope and isotype specificities of antibodies to beta -amyloid peptide for protection against Alzheimer's disease-like neuropathology. Proc Natl Acad Sci U S A 2003, 100:2023-2028.

2. Masliah E, Hansen L, Adame A, Crews L, Bard F, Lee C, Seubert P, Games D, Kirby L, Schenk D: Abeta vaccination effects on plaque pathology in the absence of encephalitis in Alzheimer disease. Neurology 2005, 64:|29-131.

3. Nicoll JA, Wilkinson D, Holmes C, Steart P, Markham H, Weller RO: Neuropathology of human Alzheimer disease after immunization with amyloid-beta peptide: a case report. Nat Med 2003, 9:448-452. 
4. Orgogozo JM, Gilman S, Dartigues JF, Laurent B, Puel M, Kirby LC, Jouanny P, Dubois B, Eisner L, Flitman S, Michel BF, Boada M, Frank $A$, Hock C: Subacute meningoencephalitis in a subset of patients with AD after Abeta42 immunization. Neurology 2003, 61:46-54

5. Cummings BJ, Satou T, Head E, Milgram NW, Cole GM, Savage MJ, Podlisny MB, Selkoe DJ, Siman R, Greenberg BD, Cotman CW: Diffuse plaques contain $C$-terminal $A$ beta 42 and not $A$ beta 40: evidence from cats and dogs. Neurobiol Aging 1996, 17:653-659.

6. Nicoll JA, Yamada M, Frackowiak J, Mazur-Kolecka B, Weller RO: Cerebral amyloid angiopathy plays a direct role in the pathogenesis of Alzheimer's disease. Pro-CAA position statement. Neurobiol Aging 2004, 25:589-597.

7. Schenk D, Barbour R, Dunn W, Gordon G, Grajeda H, Guido T, Hu K, Huang J, Johnson-Wood K, Khan K, Kholodenko D, Lee M, Liao Z, Lieberburg I, Motter R, Mutter L, Soriano F, Shopp G, Vasquez N, Vandevert C, Walker S, Wogulis M, Yednock T, Games D, Seubert P: Immunization with amyloid-beta attenuates Alzheimer-disease-like pathology in the PDAPP mouse. Nature 1999, 400:173-177.

8. Chauhan NB, Siegel GJ: Intracerebroventricular passive immunization with anti-Abeta antibody in Tg2576. J Neurosci Res 2003, 74:142-147.

9. Radaev S, Sun PD: Recognition of IgG by Fcgamma receptor. The role of Fc glycosylation and the binding of peptide inhibitors. J Biol Chem 200I, 276: 16478-I6483.

10. Mimura Y, Sondermann P, Ghirlando R, Lund J, Young SP, Goodall M, Jefferis R: Role of oligosaccharide residues of IgGI-Fc in Fc gamma RIlb binding. J Biol Chem 200I, 276:45539-45547.

II. Wilcock DM, DiCarlo G, Henderson D, Jackson J, Clarke K, Ugen KE, Gordon MN, Morgan D: Intracranially administered anti-Abeta antibodies reduce beta-amyloid deposition by mechanisms both independent of and associated with microglial activation. J Neurosci 2003, 23:3745-375I.

12. Terry RD: The pathogenesis of Alzheimer disease: an alternative to the amyloid hypothesis. J Neuropathol Exp Neurol 1996 55: $1023-1025$

13. Hardy J, Selkoe DJ: The amyloid hypothesis of Alzheimer's disease: progress and problems on the road to therapeutics. Science 2002, \% I 9(297):353-356.

14. D'Andrea MR, Cole GM, Ard MD: The microglial phagocytic role with specific plaque types in the Alzheimer disease brain. Neurobiol Aging 2004, 25:675-683.

15. Hobbs SM, Jackson LE, Hoadley J: Interaction of aglycosyl immunoglobulins with the IgG Fc transport receptor from neonatal rat gut: comparison of deglycosylation by tunicamycin treatment and genetic engineering. Mol Immunol 1992, 29:949-956.

16. Dodart JC, Bales KR, Gannon KS, Greene SJ, DeMattos RB, Mathis C, DeLong CA, Wu S, Wu X, Holtzman DM, Paul SM: Immunization reverses memory deficits without reducing brain Abeta burden in Alzheimer's disease model. Nat Neurosci 2002, 5:452-457.

17. Ferrer I, Boada RM, Sanchez Guerra ML, Rey MJ, Costa-Jussa F: Neuropathology and pathogenesis of encephalitis following amyloid-beta immunization in Alzheimer's disease. Brain Pathol 2004, I 4: II-20.

18. Deane R, Sagare A, Hamm K, Parisi M, LaRue B, Guo H, Wu Z, Holtzman DM, Zlokovic BV: IgG-assisted age-dependent clearance of Alzheimer's amyloid beta peptide by the blood-brain barrier neonatal Fc receptor. J Neurosci 2005, 25: I | 495- I I 503.

19. Gordon MN, King DL, Diamond DM, Jantzen PT, Boyett KV, Hope CE, Hatcher JM, DiCarlo G, Gottschall WP, Morgan D, Arendash GW: Correlation between cognitive deficits and Abeta deposits in transgenic APP+PSI mice. Neurobiol Aging 200I, 22:377-385.

20. DeMattos RB, Bales KR, Cummins DJ, Paul SM, Holtzman DM: Brain to plasma amyloid-beta efflux: a measure of brain amyloid burden in a mouse model of Alzheimer's disease. Science 2002, 295:2264-2267.

21. Cummings BJ, Head E, Afagh AJ, Milgram NW, Cotman CW: Betaamyloid accumulation correlates with cognitive dysfunction in the aged canine. Neurobiol Learn Mem 1996, 66: II-23.

22. Radaev S, Sun P: Recognition of immunoglobulins by Fcgamma receptors. Mol Immunol 2002, 38:1073-1083.
23. Wilcock DM, Munireddy SK, Rosenthal A, Ugen KE, Gordon MN Morgan D: Microglial activation facilitates Abeta plaque removal following intracranial anti-Abeta antibody administration. Neurobiol Dis 2004, I 5: I I-20.

24. Wilcock DM, Rojiani A, Rosenthal A, Subbarao S, Freeman MJ, Gordon MN, Morgan D: Passive immunotherapy against Abeta in aged APP-transgenic mice reverses cognitive deficits and depletes parenchymal amyloid deposits in spite of increased vascular amyloid and microhemorrhage. I Neuroinflammation 2004, I:24.

25. Dickey CA, Gordon MN, Mason JE, Wilson NJ, Diamond DM, Guzowski JF, Morgan D: Amyloid suppresses induction of genes critical for memory consolidation in APP + PSI transgenic mice. J Neurochem 2004, 88:434-442.

26. Chen QS, Kagan BL, Hirakura Y, Xie CW: Impairment of hippocampal long-term potentiation by Alzheimer amyloid betapeptides. J Neurosci Res 2000, 60:65-72.

27. Dodart JC, Mathis C, Ungerer A: The beta-amyloid precursor protein and its derivatives: from biology to learning and memory processes. Rev Neurosci 2000, I I:75-93.

28. Westerman MA, Cooper-Blacketer D, Mariash A, Kotilinek L, Kawarabayashi T, Younkin LH, Carlson GA, Younkin SG, Ashe KH: The relationship between Abeta and memory in the Tg2576 mouse model of Alzheimer's disease. J Neurosci 2002, 22:1858-1867.

29. Puolivali J, Wang J, Heikkinen T, Heikkila M, Tapiola T, van Groen T, Tanila H: Hippocampal A beta 42 levels correlate with spatial memory deficit in APP and PSI double transgenic mice. Neurobiol Dis 2002, 9:339-347.

30. Terry RD, Masliah E, Salmon DP, Butters N, DeTeresa R, Hill R, Hansen LA, Katzman R: Physical basis of cognitive alterations in Alzheimer's disease: synapse loss is the major correlate of cognitive impairment. Ann Neurol I991, 30:572-580.

31. Cummings BJ, Su JH, Geddes JW, Van Nostrand WE, Wagner SL, Cunningham DD, Cotman CW: Aggregation of the amyloid precursor protein within degenerating neurons and dystrophic neurites in Alzheimer's disease. Neuroscience 1992, 48:763-777.

32. Chauhan NB, Siegel GJ: Efficacy of anti-Abeta antibody isotypes used for intracerebroventricular immunization in TgCRND8. Neurosci Lett 2005, 375: I43-147.

33. D'Andrea MR, Cole GM, Ard MD: The microglial phagocytic role with specific plaque types in the Alzheimer disease brain. Neurobiol Aging 2004, 25:675-683.

34. Naslund J, Haroutunian V, Mohs R, Davis KL, Davies P, Greengard P, Buxbaum JD: Correlation between elevated levels of amyloid beta-peptide in the brain and cognitive decline. JAMA 2000, 283: 157 I-1577.

35. Pfeifer M, Boncristiano S, Bondolfi L, Stalder A, Deller T, Staufenbiel $M$, Mathews PM, Jucker M: Cerebral hemorrhage after passive anti-Abeta immunotherapy. Science 2002, 298: 1379

36. Janus C, Pearson J, McLaurin J, Mathews PM, Jiang Y, Schmidt SD Chishti MA, Horne P, Heslin D, French J, Mount HT, Nixon RA, Mercken M, Bergeron C, Fraser PE, St George-Hyslop P, Westaway D: A beta peptide immunization reduces behavioural impairment and plaques in a model of Alzheimer's disease. Nature 2000, 408:979-982.

37. Dickey CA, Morgan DG, Kudchodkar S, Weiner DB, Bai Y, Cao C, Gordon MN, Ugen KE: Duration and specificity of humoral immune responses in mice vaccinated with the Alzheimer's disease-associated beta-amyloid I-42 peptide. DNA Cell Biol 2001, 20:723-729.

38. Bard F, Cannon C, Barbour R, Burke RL, Games D, Grajeda H, Guido T, Hu K, Huang J, Johnson-Wood K, Khan K, Kholodenko D, Lee M, Lieberburg I, Motter R, Nguyen M, Soriano F, Vasquez N, Weiss K, Welch B, Seubert P, Schenk D, Yednock T: Peripherally administered antibodies against amyloid beta-peptide enter the central nervous system and reduce pathology in a mouse model of Alzheimer disease. Nat Med 2000, 6:916-919.

39. Coloma MJ, Clift A, Wims L, Morrison SL: The role of carbohydrate in the assembly and function of polymeric IgG. Mol Immunol 2000, 37:1081-1090.

40. Gordon MN, Holcomb LA, Jantzen PT, DiCarlo G, Wilcock D, Boyett KW, Connor K, Melachrino J, O'Callaghan JP, Morgan D: Time course of the development of Alzheimer-like pathology in the doubly transgenic PSI+APP mouse. Exp Neurol 2002, 173:183-195. 